\title{
INTEGRATION OF GREEN THINKING INTO LEAN FUNDAMENTALS BY THEORY OF INVENTIVE PROBLEMS-SOLVING TOOLS
}

\author{
BASHKITE, V[iktoria] \& KARAULOVA, T[atyana]
}

\begin{abstract}
Population of planet is growing constantly. According to United Nations official report of different projections there will be about 10 billion inhabitants on the Earth by 2050. Two out of three persons will live in the city. These facts force today's' manufacturers to find more innovative ways to satisfy future customers' needs from energy perspective and, on the other end, to take care of environment. Already today there is a certain need in set of specific rules for the companies to become more efficient and environment friendly at the same time. The combined approach of lean fundamental thinking with green manufacturing perspective analyzed with TRIZ (Theory of Inventive Problems-Solving) methodology is proposed in order to distinguish this target. The results are analyzed from Lean and Green wastes perspective on the basis of unified matrix. The main target of research is to create the short and clear guide for the manufacturers from where to start their way to innovative, environmental friendly and profitable manufacturing.
\end{abstract}

Keywords: lean manufacturing system, green manufacturing system, TRIZ tools

\section{INTRODUCTION}

Over the years, due to the availability and advancement in technology, environmental issues and governmental regulations concerning the manufacturing industry has become a problem that cannot be discarded as it has been in the past. Strict regulations have set certain limits for manufacturers, what have to be taken into account by scientists.

The fundamental purpose of the greening effort is to help to increase quality of life. Furthermore, it is to improve the quality of green compliant products and processes, and simultaneously reduce cost, pollution, the carbon and the environmental footprint of all product design, manufacturing and related activities. This includes raw material processing, warehousing, transportation, logistics, remanufacturing, recycling, and even reuse of products. The development strategy of ecoindustrial as a basis of circular economy is moving towards closing processing and manufacturing loops in industrial systems [1].

Different governmental and third party organizations develop plans to evolve new and more complex regulations, standards, and methodologies for different industries in order to save the planet for the future residents. If the company decides to implement more relevant way of production, it is easy to get lost in all these methodologies, tools, and techniques. Top management does not have much time, resources, and manpower to try different ones.
Obviously, it is time to move from lean manufacturing to green one, from ISO 9001 to ISO 140001 standard in order to fulfill all necessary requirements and keep our planet in safe. Lean and Green paradigms have a lot in common, but there are also certain contradictions. All of them are described in details in Chapter 4. This research is divided into two major parts. One part is dedicated to contradictions solving between lean and green manufacturing systems. The second fraction is about guide formation approach. This guide must be clear, specific, and easily manageable.

In fact, lean thinking is already very deeply integrated inside many companies. That means the new approach must be based on lean philosophy and keep all the best from it. Green thinking will provide the update to lean techniques from environmental point of view. There is only one question how to solve these contradictions. TRIZ methodology is going to help on this topic. Theory of Inventive Problem Solving is very rich on different interesting tools and principles.

Purpose of this research is elaboration methodology for green efforts implementation in industrial enterprises. It must help managers of various industries to find the right way for saving resources, money, and environment. Likewise new methodology helps to evaluate the wastes of companies' activities from Lean and Green manufacturing systems point of view. Analysis of possible solutions is done on the basis of Lean \& Green wastes matrix.

\section{BRIEF LITERATURE REVIEW}

Green manufacturing system that focuses on minimizing environmental impact of manufacturing processes and products is ever more important to our sustainable future. Lean manufacturing system is generally considered the most competitive manufacturing system in the world. In recent years, researchers and the USE Environmental Protection Agency (EPA) have sought to "build a bridge" between Lean and Green manufacturing systems, in hopes that the rapid expanse of Lean can serve as a catalyst to the implementation of Green manufacturing system [2].

International interest in proactive environmental management systems led to the creation of ISO14000, an international Environmental Management System (EMS) standard, in the mid 1990's. All of these approaches to improving the environmental performance of companies are categorized under the subject of Green manufacturing. 
Growing interest in both Lean and Green manufacturing systems led to natural curiosity about their potential relationship. The findings from an MIT research effort indicate a relationship between Lean manufacturing and innovative environmental practices [3]. Wallace et al. indicated that both radical technology innovation and continuous improvement (e.g. kaizen) created significant opportunities for pollution prevention [4]. Researchers at the University of Michigan found that efforts to prevent pollution and reduce emissions had a positive effect on industrial performance [5].

A small number of scholarly studies have investigated the relationship between Lean and Green manufacturing systems [6], [7], [8] and [9]. These studies show a positive relationship between Lean and Green.

There are certain toolkits \& programs developed to help enterprises to become greener on lean basis. One of the most famous ones is EPA's Lean \& Environment Toolkit [10]. There are some good results achieved in Washington Projects by involvement of the next organizations as the Washington State Department of Ecology (Ecology), and the Washington Manufacturing Extension Partnership (MEP), Impact Washington (IW). These partners worked together to conduct three successful pilot projects in Washington [11]. Some work is done by consulting companies and non-profit unions as IMC Consulting with Green Supplier's Network (GSN) Program) [12], Society of Manufacturing Engineers Lean to Green Technical Group, Pollution Prevention Resource Center (PPRC) [13].

The idea is to develop another simple guide on basis of Lean and Green manufacturing systems for industrial engineers what have to be reachable, understandable, and easy to use in workaday life.

\section{THE IDEAL FINAL RESULT (IFR)}

The Ideal Final Result (IFR) is the TRIZ technique enables formulating target solutions in terms of ideality. Formulation of the Ideal Final Result helps to correctly set up goals, fight mental inertia, and design costseffective products and services [14].

What is the ideality in terms of production system today? Production with zero-waste is the dream and aim for every manufacturing company. In general, nowadays that means the waste of one production process must be the raw material for another one. The true challenge for the researchers is to convert $\mathrm{CO}_{2}$ emissions into raw material. There are certain projects launched and papers written in order to solve this problem [15]. The combination of lean and green manufacturing techniques is chosen per purpose. The ideal production system from lean perspective eliminates any kind of waste from every process while adding value for the customers [16]. The green ideal manufacturing system targets the elimination of waste from every activity while adding value for the environment. The idea is to combine these two visions and eliminate waste while adding value to customers and environment.

The framework of new approach is suggested in Fig. 1. First of all, similarities and contradictions of two paradigms are described. The problem of combining two manufacturing systems is hidden in contradictions. Every conflict must be solved and can be evaluated through the Lean \& Green Wastes Matrix. In that case, it is better to realize how harmful the contradiction from both theories point of view. Tools of TRIZ help to find the possible solutions to specific contradictions. When the solutions are developed, the Lean \& Green Wastes Matrix gives the assessment how good is solution for this specific conflict. By analyzing all the conflicts and finding solution for them, the new approach is developed.

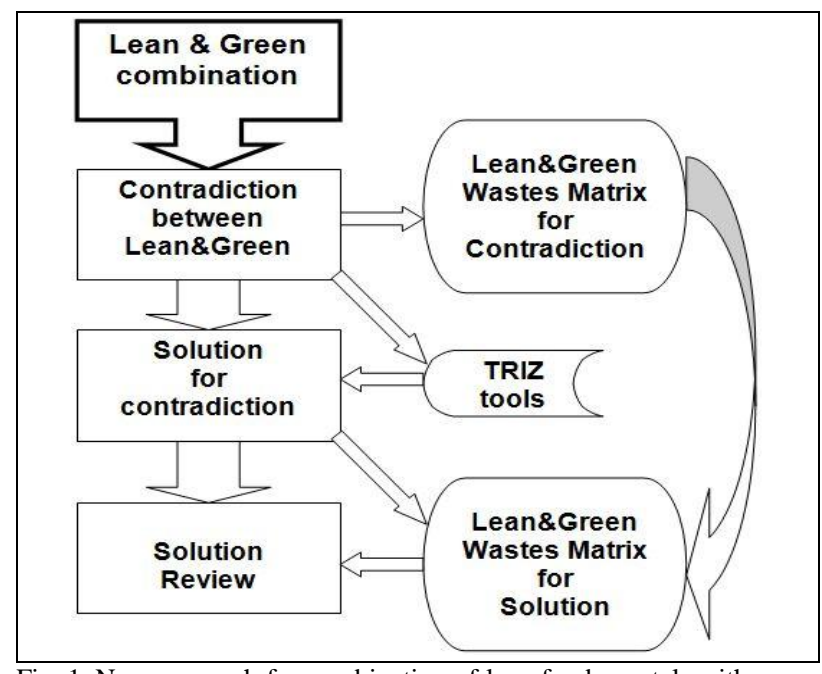

Fig. 1. New approach for combination of lean fundamentals with green way of thinking through TRIZ methodology

\section{LEAN AND GREEN MANUFACTURING SYSTEMS}

\subsection{Lean manufacturing philosophy}

Lean Manufacturing fundamental idea is a continuous improvement (Kaizen). "Continuous improvement is striving for perfection by continually removing successive layers of waste, as they are discovered. Generally, it is accepted, that compete transformation process from mass production to Lean Manufacturing takes years. Perfection is zero waste. The progress cannot be benchmarked against competitors' levels of waste, but requires striving world-class performance [17].

Lean manufacturing is our present. Many companies have a good experience with different tools and techniques. Next step is toward respect to environment.

\subsection{Green manufacturing philosophy}

Perfect explanation of Green Manufacturing philosophy was given by David Foster (Blue Green Alliance). Foster explains, "Green Manufacturing is a philosophy rather than an adopted process, because it motivates ongoing improvement efforts, even though it may be impossible to achieve". The important beginning for the Green Manufacturing is environmental standard ISO 14001.

\subsection{Lean and Green manufacturing similarities}

Thinking more about the similarities between lean implementations and environmental impact reduction, further parallels begin to appear; for example, lean value stream thinking deep understanding of all the processes required manufacturing a product, which is quite similar to the preparation required for life cycle analysis to assess environmental impacts [18]. Certain benefits of 
combining lean and green manufacturing are hidden in next similarities:

a. Good similarity is the connection with ISO standards. Implementation of ISO14001 standard is the continuation of Lean Manufacturing techniques improvement and strong beginning for Green Manufacturing integration [19].

b. Both manufacturing systems involve the workforce of the whole company from general workers to top management.

c. Integration of Lean and Green principles help companies to improve efficiency and save money.

d. There is a strong connection between lean and green principles around waste management [20].

e. Both Lean and Green philosophies are looking for how to integrate the end-of-life strategies into product and process redesign [21] and [22].

It can be said that lean is green. The obvious benefits of green and lean are energy savings, productivity increment, and advantages/benefits from improved utilization of materials. They can also lead to innovations that involve creation of new products out of waste materials.

\subsection{Lean and Green manufacturing conflicts}

As there are similarities between these two manufacturing systems, still there are certain arguing points. It is not easy to integrate one system into another one. Franchetti et al. [23] discovered the real problem of combining two philosophies is hidden in the nature of environment. Lean considers the environment as a valuable resource, though green looks at the environment as limitation for product and services design and production. Next specific contradictions present during combination of lean and green principles:

a. Use of harmful for environment materials is usual practice for lean manufacturing in order to raise the quality of final product with effective cost. It is impossible from green perspective [24].

b. One of the most critical otherness lies under replenishment frequencies. Lean calls for an increase in the replenishment frequencies whereas Green manufacturing system aims the reduction of replenishment frequencies [25] and [26].

c. Lean prescribes the reduction of inventory; on the other hand green practices can suffer from greater production of waste [27].

d. Lean practices do not aim the reduction of $\mathrm{CO}_{2}$ emissions; thereby green main idea is decrease of all possible pollutions what are emerging during the production process.

e. However, although the two paradigms have different objectives for waste elimination, they target not the same type of wastes [20].

f. The Lean and Green ways of production target different type of customer. The Lean customer seeks for the cost-effective product with reasonable lead time [26] and [28]. Green customer over against lean one is interested in the products and services what are produced and provided with Green principles - in environmentally friendly way [29], [30], [31], [32], and [33].

g. Product design from lean perspective does not cover the end-of-life scenarios. Lean idea is to increase the performance and quality by cost cutting. Green seeks for less scrap through considering different scenarios by product life cycle planning procedure from the product design phase [34] and [35, 43].

h. Lean theory is well researched and known for the engineers. Green is still on the way. Techniques and tools of green manufacturing must be better described and stated.

Many manufacturers know the benefits of lean manufacturing: higher productivity, better quality, reduced cycle time, plus enhanced employee engagement (see Fig. 2). Environmental waste is any unnecessary use of resources or a substance released into the air, water, or land that could harm human health or the environment. Environmental wastes are often a sign of inefficient production, and they frequently indicate opportunities for saving cost and time.

Despite the relationships between Lean's 7 wastes and environmental wastes, many Lean implementation efforts often overlook opportunities to prevent or reduce environmental wastes. All environmental wastes may be summarized to 5 main types:

1. Water: leaks, waste streams from processes.

2. Air: evaporation of chemicals, dust, particulate.

3. Solid Waste: filters, excess material scrap.

4. Toxic \& Hazardous Waste: solvents, process residuals.

5. Energy: machinery on when not in use, heat loss, oversized motors.

These five wastes raise awareness of the opportunities for improvements that not only affect the process, but also working conditions and overall environmental impact [36].

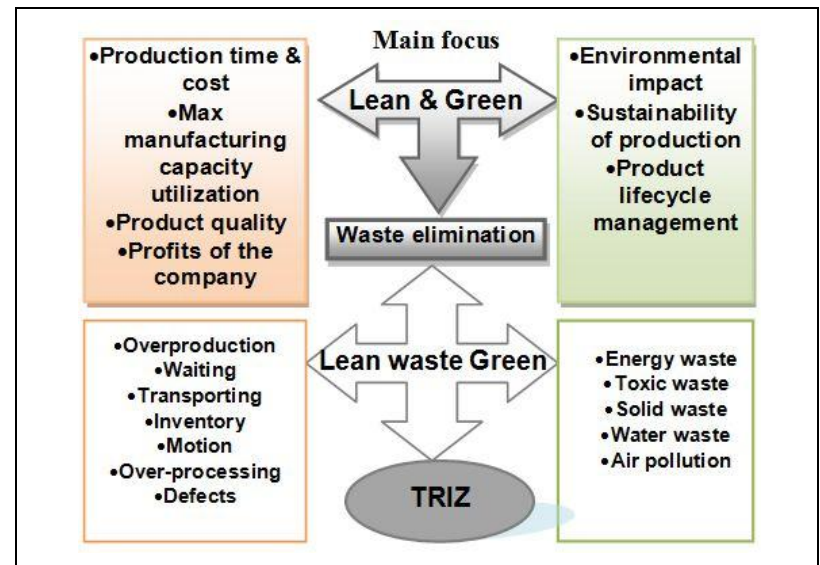

Fig. 2.General view on Lean and Green approaches from Waste point of view

\section{THEORY OF INVENTIVE PROBLEM- SOLVING (TRIZ) AS A METHODOLOGY FOR CONTRADICTIONS SOLVING}

Theory of Inventive Problem-Solving (TRIZ) is a creative problem-solving methodology especially tailored 
for scientific and engineering problems. The TRIZ philosophy is based on the fact that the evolution of a design is not a random process. The TRIZ's major discovery was revealing the origin of an inventive problem, which is defined as a "contradiction". A contradiction arises when two mutually exclusive design requirements are put on the same object or system. When a designer faces a contradiction that cannot be solved by redesigning a technical system in a known way, this means that he faces the inventive problem, and its solution principle resides outside the domain the technical system belongs to. There are two ways to solve problems that contain contradictions: by finding a compromise between two conflicting parameters or by eliminating the contradiction. TRIZ is aimed at solving problems by eliminating the contradictions. The main difference between the TRIZ methodology and all other innovative or creative methods is the reduction of ineffective solutions by using a purposeful and systematical procedure and by passing over the psychological inertia barrier. The method of TRIZ is to break the psychological barrier, to abstract the initial problem [37].

\subsection{Tools of TRIZ}

There are a number of TRIZ approaches that can be used throughout the contradiction solving. Most updated version described in Annotated List of Key TRIZ Components and Techniques by Souchkov [14]. Most useful tools for general solution are Function Analysis, The Contradiction Matrix, the Forty Principles, The Ideal Final Result (IFR), and The Algorithm for Inventive Problem Solving (ARIZ) and Trends of Evolution.

These are main tools often used in problems solving. Some of them are already used in the current research and the rest of them will be described and used for the general problems solving in order to combine Lean and Green paradigms in the current research.

\subsection{The Algorithm for Inventive Problem Solving (ARIZ)}

ARIZ is an acronym for the Russian phrase "Algorithm for Inventive Problem Solving," ARIZ is a logical structured process that incrementally evolves a complex problem to a point where it is simple to solve. ARIZ, therefore, is best used for complex problems. Complex problems cannot be solved in just two steps. For those problems which are so complex, that they cannot be solved with any other tools, TRIZ includes the algorithm ARIZ to follow which will facilitate the problem-solving process. ARIZ is not an equation, but rather a multi-step process asking you a series of questions that integrates different pieces of TRIZ. ARIZ is a very "solution neutral" process: i.e., it takes preconceived solutions out of the problem statement [38].

\subsection{The Forty Principles (40 Principles)}

Inventive Principles for technical contradiction elimination are used to eliminate problems represented in terms of technical contradictions. Inventive Principles describe either solution pattern which can be applied to resolve the contradiction, or a direction in which a problem has to be solved. There are 40 inventive principles for resolving technical contradictions available in TRIZ (some TRIZ extensions present 50 principles) [14].

\subsection{The Contradiction Matrix}

The first technique and still the most popular one was developed by Altshuller in the sixties. Based on the analysis of over 400.000 patents intentionally drawn from different areas of technology, the matrix helps to identify which of 40 Inventive Principles are most relevant to solve problems represented as contradictions: a technical parameter to be improved versus another parameter of the system that gets worse when implementing such an improvement. TRIZ states, that to obtain inventive solution the contradiction has to be eliminated while no compromising is allowed. The necessity to eliminate contradictions is the driving force of technological progress. Altshuller Matrix allows the principles for technical contradiction elimination to be used in a systematic way. The matrix was designed on the basis of 39 generalized parameters any specific parameter is claimed to be possible to associate with. The same lists of parameters are placed along vertical and horizontal axes of the matrix. A point of intersection of two generalized parameters indicates which inventive principle(s) is to be used in each particular situation [14].

\section{CONTRADICTION SOLVING WITH TRIZ AND POSSIBLE SOLUTION ANALYSIS BY USING LEAN \& GREEN WASTES MATRIX}

\subsection{Physical Contradiction (PC) finding by using ARIZ-85B logic}

One of the most critical otherness lies under replenishment frequencies.

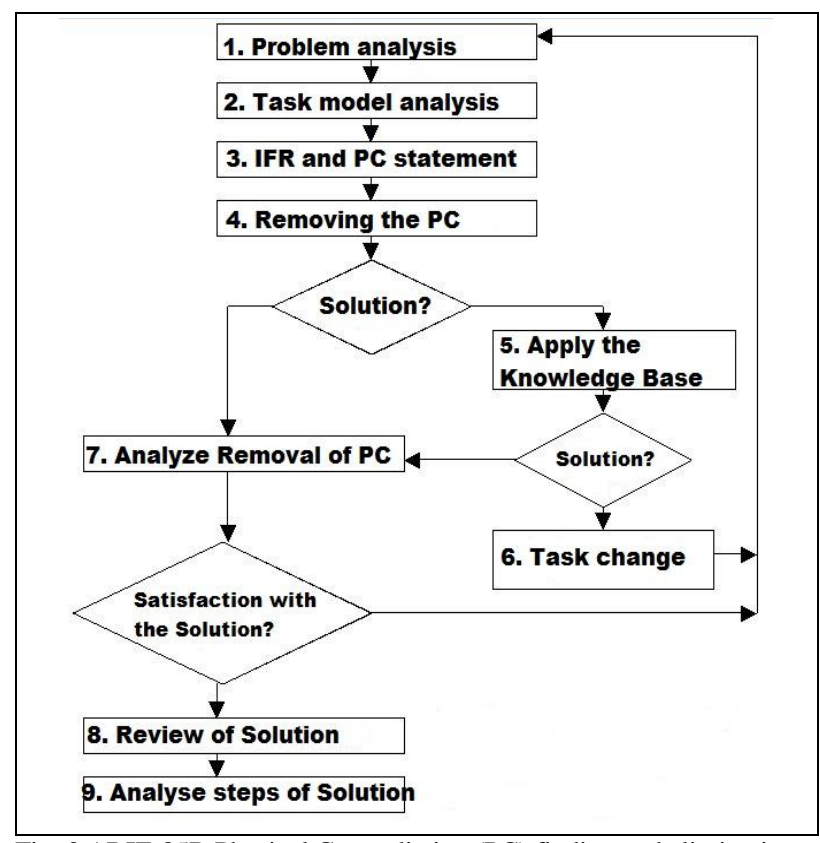

Fig. 3.ARIZ-85B Physical Contradiction (PC) finding and elimination

Lean calls for an increase in the replenishment frequencies whereas Green manufacturing system aims the reduction of replenishment frequencies. This technical contradiction is transferred into Physical Contradiction (PC) and possible solutions are proposed according to Algorithm for Inventive Problem Solving85B (ARIZ-85B). The framework ARIZ-85B is described in Fig. 3. 
The specified contradiction (above) is analyzed according to following framework at Fig. 4. Firstly, the problem is designated. Then the task model is specified and analyzed step by step as it is written in the book [39]. Step 3 is to describe the Ideal Final Result (IFR) and state the Physical Contradiction (PC). Also it is done step by step with the attention to the resources outside and inside the technical system (TS). By removing PC different possible solutions are proposed.

\subsection{Proposal of possible solutions by using 40}

Principles and the Contradiction Matrix

After all the manipulations according to ARIZ-85B scheme, next Physical Contradiction (PC) is found: "Transportation function must be performed continuously (supply of raw material, semi-finished products and etc.), but there must be no transportation activity (no $\mathrm{CO}_{2}$ emissions)".

Next two solutions are developed by applying knowledge base of the 40 principles:

a. Principle 22 ("Turn Lemons into Lemonade") [40]. Solution A: $\mathrm{CO}_{2}$ emissions must become a raw material for this production facility or some other object. Like transportation vehicle has to intake $\mathrm{CO}_{2}$ as energy and run on it.

b. Principle 25 (Self-Service) [40]. Solution B: All the components or raw materials must be produced on place or supplied from the same area.

c. The Solution $\mathrm{C}$ is developed by the Contradiction Matrix from the online webpage resource [41]. The Interactive TRIZ Contradiction Matrix proposes by improving "Volume of moving object" and worsening feature "Use of energy by moving" the Principle nr 35, namely Parameter changes. In the current research it can be translated into next saying: "transportation function must be performed with such means of transportation what do not produce $\mathrm{CO}_{2}$ emissions (for example, electrical vehicles)". Change of object's physical state: fuel to electricity.

6.4 Proposed solutions analysis from Green and Lean wastes point of view by using Matrix approach

All the solutions must be analyzed from waste perspective. Solutions can be different and the most important part is to find the best solution from both philosophies perspective [42]. The PC is creating certain amount of wastes from Lean and Green point of view.

\begin{tabular}{|c|c|c|c|c|c|c|}
\hline & & & & Gree & & \\
\hline & Wastes & $\begin{array}{l}\text { केष } \\
\text { कूँ } \\
\text { फ़ ई }\end{array}$ & 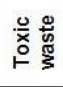 & $\begin{array}{l}\text { 응 㟧 } \\
\text { 心 }\end{array}$ & 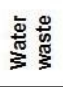 & 는 $\frac{\overline{0}}{\bar{z}}$ \\
\hline \multirow{7}{*}{ 동 } & Overproduction & & & & & \\
\hline & Waiting & & & & & \\
\hline & Transporting & & & & & \\
\hline & Inventory & & & & & \\
\hline & Motion & & & & & \\
\hline & $\begin{array}{c}\text { Over- } \\
\text { processing }\end{array}$ & & & & & \\
\hline & Defects & & & & & \\
\hline
\end{tabular}

Fig. 4. PC wastes analysis from Lean and Green perspective

Fig. 4 demonstrates possible wastes from the analyzed PC activities namely "Transportation function must be performed continuously (supply of raw material, semi-finished products and etc), but there must be no transportation activity (no $\mathrm{CO}_{2}$ emissions)".

"Arrow up" means the wastes increase from contradiction activities if there is no possible solution for it. "Equal" sign means no change from the waste perspective.

By implementing all three solutions $\mathrm{A}, \mathrm{B}$, and $\mathrm{C}$ there will be less "arrows up" in the table. That means that PC is solved and waiting for the price calculation and availability of needed solution from technical point of view.

Solution $\mathrm{C}$ is more real due to the Lean \& Green Wastes Matrix is proposed for it and presented in Fig. 5.

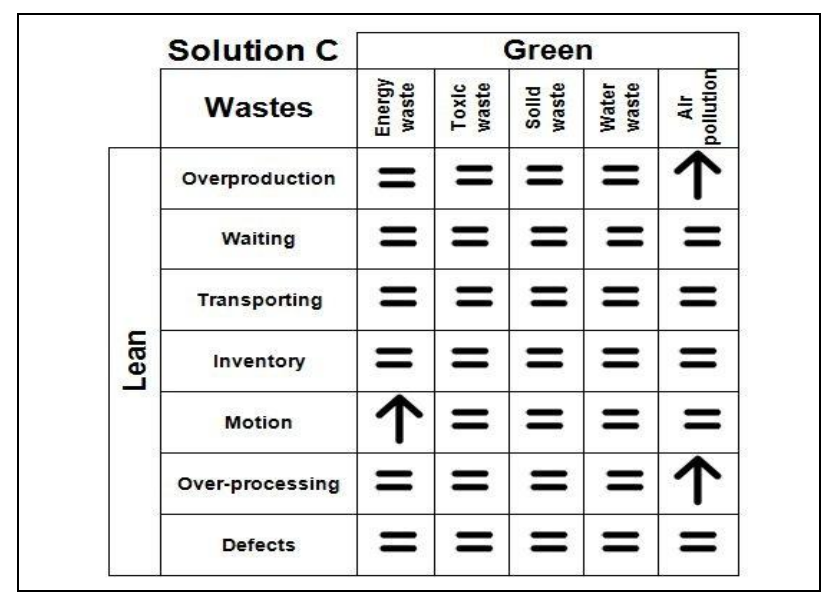

Fig. 5.Solution analysis from Lean \& Green Wastes Matrix perspective

\section{CONCLUSION}

The proposed methodology does not represent a ready-to-use methodology to the manufacturers. The proposal for the methodology has been done in a simple manner, graphically, to facilitate the understanding of the TRIZ methodology for combination of Green and Lean practices. The analysis of contradiction and solution is performed through the Lean \& Green Wastes Matrix developed on the basis of Lean \& Green wastes. As further work, the aspect of using the TRIZ tools will be analyzed for Green thinking integration into Lean fundamentals. The aim of the future research is to present the integration model by developing the matrix for contradiction solving between Lean \&Green manufacturing systems on the basis of TRIZ tools.

\section{ACKNOWLEDGEMENTS}

The research was supported by Estonian Ministry of Education and Research for targeted financing scheme SF0140035s12, grant ETF9460 and the DoRa programme Activity 6 stipend.

\section{REFERENCES}

[1] Xu1, D. W.; Wang, Z. Y. and Shi., W. Y. (2004). The Process Analysis of Industrial Metabolism Based on Chain Management, 
Environmental Informatics Archives, Volume 2 ,2004, 56-64, EIA04-007

[2] EPA (2001). An Organizational Guide to Pollution Prevention and Waste Minimization. Office of Research and Development. Washington DC: UnitedStates Environmental Protection Agency. EPA625-R-01-003

[3] Maxwell, J., S.; Rothenberg, and Schenk, B. (2001). Does Lean Mean Green? The Implications of Lean Production for Environmental Management, Working Paper, MIT, Cambridge, MA

[4] Wallace, D. (1995). Environmental Policy and Industrial Innovation: Strategies in Europe, the U.S., and Japan . London: Royal Institute of Affairs, EarthscanPublications Ltd

[5] Hart, S.; Ahuja, G. (1996). Does it pay to be green? An Empirical examination of the relationship between emissions reduction ad firm performance. Business, Strategy and the Environment, 5, 3037

[6] Florida, R. (1996) Lean and Green: the move to environmentally conscious manufacturing. Regents of the University of California

[7] Rothenberg, Sandra, Pil, Fritz, Maxwell, James (2001). Lean, green, and the quest for superior environmental performance. Production and Operations Management, 10, 228 - 244

[8] King, A.; Lenox, M. (2001), Lean and green? An empirical examination of the relationship between lean production and environmental performance. Production and Operations Management, 10 (3), 244-257

[9] EPA (2003). Lean Manufacturing and the Environment. Office of Solid Waste and Emergency Response. Washington DC: United States Environmental Protection Agency. EPA100-R-03-005

[10] http://www.epa.gov/lean/environment/toolkits/environment/index. htm, (2011). EPA, Environment Toolkits, Last updated: 15.11.2011

[11] Buffa, A. (2009). "Lean and Green" Manufacturing Program Helps Washington's Small Manufacturers Reduce Energy Use and Waste, Apollo News Service

[12] http://www.consultimc.com/solutions/lean_process.html, (2008). Consult IMC

[13] http://www.pprc.org/contacts/index.cfm?pageAction=showDetail \&region=10\&orgid $=100000556 \&$ format $=$ WDDX, Pollution Prevention Resource Center, P2 programme

[14] Souchkov, V. (2006). ICG Training \& Consulting, Annotated List of Key TRIZ Components and Techniques. Available from: http:// www.xtriz.com Accessed: 2011-11

[15] Amouroux, J.; Siffert, P. (2011). Carbon dioxide: a raw material and a future chemical fuel for a sustainable energy industry, Materials Science and Engineering, Vol. 012001, IOP Publishing

[16] Skelton, J. (2006). Lean Management for the Green Industry, Crystal Ball Report \#26. Professional Landcare Network (PLANET)

[17] Summit, G. (2008). Lean and Green Glossary, Available from: http:// www.leanandgreensummit.com Accessed: 2008-07

[18] http://www.leanenterprise.org.uk/lean-research/lean-andgreen.html, (2009). LERC - Lean Research - Lean \& Green. Lean Enterprise Research Centre

[19] Bergmiller, G.G.; McCright, P.R. (2009). Lean Manufacturers' Transcendence to Green Manufacturing, Proceedings of the 2009 Industrial Engineering Research Conference

[20] Dües, C.M.; Tan, K.H.; Lim, M. (2012). Green as the new lean: How to use lean practices as a catalyst to greening your supply chain, Journal of Cleaner Production, doi: 10.1016/ j.jclepro.2011.12.023

[21] Sarkis, J. (2003). A strategic decision framework for green supply chain management, Journal of Cleaner Production, Volume 11, Issue 4, pages 397-409

[22] Bergmiller, G.G.; McCright, P.R. (2009). Are Lean and Green Programs Synergistic?, Proceedings of the 2009 Industrial Engineering Research Conference

[23] Franchetti, M.; Bedal, K.; Ulloa, J.; and Grodek, S. (2009). Lean and Green: Industrial engineering methods are natural stepping stones to green engineering; Industrial Engineer: IE, Vol. 41, No. 9, September 2009, pp. 24-29

[24] Rothenberg, S.; Pil, F.K.; Maxwell, J. (2001). Lean, green, and the quest for superior environmental performance, Production and Operations Management, Volume 10, No 3, pages 228-243
[25] Venkat, K.; Wakeland, W. (2006). Is Lean Necessarily Green?; Pdf from Website: Proceedings of the 50th Annual Meeting of the ISSS, ISSS 2006 Papers, Available from: http://www.cleanmetrics.com/pages/ISSS06IsLeanNecessarilyGreen.pdf Accessed 2011-07

[26] Carvalho, H.; Cruz-Machado, V. (2009). Integrating Lean, Agile, Resilience and Green Paradigms in Supply Chain Management (LARG_SCM); Proceedings of the Third InternationalConference on Management Science and Engineering Management, pp. 3-14

[27] King, A.A.; Lenox, M.J. (2001). Lean and Green? An empirical examination of the relationship between lean production and environmental performance; Production and Operations Management, Volume 10, No. 3, pp. 244-256

[28] Mason-Jones, R.; Naylor, J.B.; Towill, D.R. (2000). Engineering the leagile supply chain; International Journal of Agile Management Systems, Volume 2, No. 1, pp. 54-61

[29] Hines, P., Holweg, M., and Rich, N. (2004). Learning to evolve A review of contemporary lean thinking; International Journal of Operations \& Production Management, Volume 24, No. 10, pp. 994-1011

[30] Mollenkopf, D.; Stolze, H.; Tate, W.L.; Ueltschy, M. (2010). Green, lean, and global supply chain; International Journal of Physical Distribution \& Logistics Management, Volume 40, No. $1 / 2$, pp. 14-4

[31] KPMG (2011a). Corporate Sustainability - A progress report; Corporate Sustainability: A progress report - KPMG GLOBAL, Available from: http://www.kpmg.com/Global/en/IssuesAndInsights/ArticlesPubli cations/Documents/corporatesustainability-v2.pdf; Accessed on 2011-08

[32] Yang, M. G.; Hong, P.; Modi, S.B. (2011). Impact of lean manufacturing and environmental management on business performance: An empirical study of manufacturing firms; International Journal of Production Economics, Volume 129, pp. 251-261

[33] Bashkite, V.; Moseichuk, V.; Karaulova, T. (2011). Combination of end-of-life strategies for extension of industrial equipment life cycle. Journal of Machine Engineering, 10 (4), pp. 76 - 88.

[34] Kainuma, Y.; Tawara, N. (2006). A multiple attribute utility theory approach to lean and green supply chain management; International Journal of Production Economics, Vol. 101, pp. 99108

[35] Zahharov, R.; Bashkite, V.; Karaulova, T.; Miina, A. (2010). Industrial building life cycle extension through concept of modular construction, Proceedings of the21st DAAAM World Symposium, pp 805 - 806

[36] Ikovenko, S.; Bradley, J. (2004). TRIZ as a Lean Thinking Tool, Available from: http://www.triz-journal.com/archives/2005 Accessed 2005-02

[37] Mazur, G. (2001). Theory of Inventive Problem Solving (TRIZ), Available from: http://www-personal.engin.umich.edu/gmazur/triz/ Accessed 2012-06

[38] Marconi, J. ARIZ: The Algorithm for Inventive Problem Solving, Marconi Works, International, Available from: http://www.trizjournal.com/archives/1998/04/d/index.htm Accessed 2012-04

[39] Альтшуллер, Г. (2007). Найти идею: Введение в ТРИЗ теорию решения изобретательских задач, Handbook ISBN 978-5-9614-0534-7, ООО «Алышна Бизнес Букс», 2007

[40] Zhang, J.; Chai, K-H.; Tan, K. (2003). 40 Inventive Principles with Applications in Service Operations Management, Operations Management, Volume: 4, Issue: December, pp: 1-16

[41] Interactive TRIZ Matrix \& 40 Principles, Available from: http:// www.triz40.com/ Accessed 2012-04

[42] Lõun, K.; Riives, J.; Otto, T. (2011). Evaluation of the operation expedience of technological resources in a manufacturing networ. Estonian Journal of Engineering, 17(1), 51 - 65

[43] Zahharov, R.; Shevtshenko, E.; Karaulova,T. Integrated CAD/ERP Framework for Modular Construction Industrialization Through Lean Manufacturing Concept. (2009) Annals of DAAAM For 2009\& Proceedings of the20th International DAAAM For 2009 \& Proceedings of the 20thWorld Symposium, Volume 20, pp $591-592$ 